\title{
Analisis Faktor yang Berhubungan Dengan Kejadian
} Perilaku Kekerasan Pada Remaja

\author{
Yuniar Mansye Soeli, Rhein Djunaid, Amelia Rizky, Diesy Rahman \\ Program Studi Ilmu Keperawatan Fakultas Olahraga dan Kesehatan Universitas Negeri Gorontalo \\ E-mail: yuniar_soeli@ung.ac.id
}

\begin{abstract}
Abstrak
Perilaku kekerasan pada remaja merupakan tindakan yang disengaja yang mengakibatkan cidera fisik atau tekanan mental. Perilaku kekerasan disebabkan oleh berbagai faktor yaitu faktor pengalaman psikologi, spiritual dan lingkungan. Tujuan penelitian untuk mengetahui hubungan pengalaman psikologi, spiritual dan lingkungan dengan perilaku kekerasan pada siswa baru. Jenis penelitian adalah survey analitik dengan pendekatan cross sectional. Penelitian dilaksanakan Di SMKN 3 Kota Gorontalo. Populasi seluruh siswa baru di SMKN 3 Kota Gorontalo dengan jumlah sampel yang diperoleh dari teknik accidental sampling. Hasil penelitian menunjukkan bahwa terdapat hubungan antara faktor pengalaman psikologis, spiritual dan lingkungan dengan perilaku kekerasan pada remaja $(0,000)<\alpha(0,05)$. Saran diharapkan agar terapi ini dapat diberikan dalam upaya pencegahan terjadinya perilku kekerasan pada remaja.
\end{abstract}

Kata kunci: perilaku kekerasan, remaja

\begin{abstract}
Violent behavior in adolescents is a deliberate act that results in physical injury or mental stress. Violent behavior is caused by various factors, namely psychological, spiritual and environmental experience factors. The aim of the study was to determine the relationship between psychological, spiritual and environmental experiences with violent behavior in new students. This type of research is an analytical survey with a cross sectional approach. The research was conducted at SMKN 3 in Gorontalo City. The population of all new students at SMK 3 in Gorontalo City with the number of samples obtained from the accidental sampling technique. The results showed that there was a relationship between experience, psychological, spiritual and environmental factors with violent behavior in adolescents $(0,000)<\alpha(0.05)$. Suggestions are expected that this therapy can be given in an effort to prevent the occurrence of behavior in adolescents .
\end{abstract}

Keywords: violent behavior, teenagers

\section{PENDAHULUAN}

Kekerasan merupakan tindakan yang disengaja yang mengakibatkan cidera fisik atau tekanan mental (Carpenito \& Moyet, 2016). Campbell dan Humphey mendefinisikan kekerasan anak yaitu setiap tindakan yang mencelakakan/dapat mencelakakan kesehatan dan kesejahteraan anak yang dilakukan oleh orang yang seharusnya bertanggung jawab. Orang yang bertanggung jawab dalam hal ini adalah keluarga, teman, maupun lingkungan masyarakat disekitar anak (Yani, 2008).

Data tindak kekerasan dunia menurut UNICEF pada tahun 2017, setiap 7 menit di suatu daerah di dunia, seorang remaja terbunuh akibat tindak kekerasan. Remaja yang berada pada kisaran umur 15-19 tahun memiliki peluang tiga kali lebih tinggi untuk meninggal daripada remaja usia 10-14 tahun. (UNICEF, 2017). Untuk data kekerasan di Indonesia, didapatkan berdasarkan hasil Survey Kekerasan Terhadap Anak (SKTA) tahun 2013. Dalam hasil survey yang dilakukan pada responden yang berusia 13-17 tahun mengenai pengalaman kekerasan yang dialami di 12 bulan terakhir, ditemukan bahwa 1 dari 4 anak laki- laki diperkirakan pernah mengalami kekerasan fisik, 1 dari 8 pernah mengalami kekerasan emosional dan 1 dari 12 anak pernah mengalami kekerasan seksual. Sedangkan hasil tindak kekerasan pada anak perempuan didapatkan 1 dari 7 anak perempuan pernah mengalami kekerasan fisik, 1 dari 9 mengalami 
kekerasan emosional dan 1 dari 19 anak mengalami kekerasan seksual.

Badan Kependudukan dan Keluarga Berencana Nasional Kota Gorontalo menyatakan telah terjadi 204 kasus kekerasan pada tahun 2015, di tahun 2016 tercatat 146, dan 102 kasus di tahun 2017. Dari 146 kasus yang terjadi di tahun 2016, terdapat 43 kasus kekerasan dialami oleh remaja. Sedangkan di tahun 2017, ditemukan 47 dari 102 kasus kekerasan dialami oleh remaja. Berdasarkan wawancara dengan pegawai yang menangani bidang perlindungan wanita dan anak, beliau mengatakan bahwa data yang terangkum di BKKBN berasal dari laporan kepolisian maupun dari 9 kecamatan di kota Gorontalo. Data yang tercantum terlihat menurun tiap tahunnya.

Perilaku kekerasan ini disebabkan oleh berbagai faktor baik faktor internal seperti pengalaman psikologis dan kondisi spiritual maupun dari luar seperti lingkungan. Dari segi aspek pengalaman psikologis, menurut Trisnawati tahun 2014 dengan judul faktor yang mempengaruhi sifat agresif remaja menyatakan bahwa seseorang belajar melalui pengalaman langsung atau pengamatan tidak langsung (mencontoh model) seperti apa yang ia baca, dengar dan lihat di media dan juga dari orang lain dan lingkungannya. Berdasarkan pengalaman yang mereka peroleh, maka perilaku agresif tersebut cenderung bertahan dan terus diulang. Remaja juga mudah terpengaruh oleh lingkungan sosialnya, baik berupa pengaruh positif maupun negatif. Tidak hanya perilaku agresif saja namun juga perilaku- perilaku lainnya seperti membully, berjudi, melakukan perilaku seks pranikahdanlain-lain. Pengaruh negatif inilah yang akan berdampak pada psikologi remaja apabila terus menerus terpapar dengan perilaku kekerasan.

Pada aspek spiritual berdasarkan penelitian yang dilakukan oleh Palupi (2013) menemukan bahwa nilai spiritual atau religiusitas memiliki hubungan negatif dengan kenakalan remaja. Dengan kata lain, semakin tinggi religiusitas yang dimiliki remaja maka semakin rendah tingkat kenakalan remaja dan sebaliknya, semakin rendah religiuitas yang dimiliki remaja, semakin tinggi tingkat kenakalannya. Contohnya siswa menjadi agresif akibat kurangnya control diri dalam hal ini adalah tingkat spiritual yang dimiliki oleh siswa itu sendiri. Untuk data awal spiritual tidak terdokumentasi disekolah.

Berdasarkan hasil observasi di SMKN 3 Kota Gorontaloterlihatbahwa perilakuperilaku menyimpang terdapat pada siswa seperti berteriak padagurudan memaki guru atau pun teman.Perilaku menyimpang ini terlihat pada siswa lama dan pada siswa baru cenderung lebih banyak yang diam namun ada beberapa siswa baru yang juga memperlihatkan sikap yang kurang baiksepertiterlambat saat berkumpul di sekolah, berteriak-teriak di jalan dan merokok diluarsekolah saat mereka istirahat. Perilaku-perilaku seperti ini akan mempengaruhi pembawaan siswa nantinya saat mulai bersekolah di sekolah yang baru yang nantinya akan berdampak pada kenakalan remaja bahkan pada perilaku kekerasan.

Berdasarkan hasil wawancara dengan salah satu siswa disekolah tersebut, siswa mengungkapkan bahwa akibat pengalaman yang didapat dari orangtua terdahulu bahwa siswa sering dipukul sehingga menyebabkan mereka melakukan perilaku kekerasan. Selain itu, siswa mengaku tidak memperdulikan tindakan yang dilakukan 
walaupun hal tersebut bertentangan dengan agama. Karena menurut mereka saat ada hal yang membuat kemarahannya terpancing, maka siswa harus menyelesaikannya dengan tindakan kekerasan.

Selain itu, peneliti juga mencoba melakukan pencarian mengenai tindak kekerasan di sekolah tersebut dan menemukan video yang memperlihatkan siswa SMKN 3 melakukan tawuran. Tidak hanya itu, terdapat pula video yang menampilkan gerombolan siswa yang tidak sabaran akibat pintu pagar yang lama dibuka penjaga sekolah. Mereka berteriak seenaknya, memaki, dan pula yang memperlihatkan aksi mengangkat motor ke arah temannya. Dari hasil observasi dan pengecekan dalam sosial media ini menimbulkan kesan bahwa sekolah ini memiliki siswa dengan perilaku kekerasan yang cenderung tinggi. Untuk data penunjang dari BK (bimbingan konseling) mengenai kekerasan dalam jangka waktu tiap bulan sangat sulit didapatkan karena perilaku-perilaku menyimpang ini kadang tidak di usut lebih lanjut di bimbingan konseling. Sehingga data tindak kekerasan tidak dimiliki atau tercatat secara pasti.
Dari data-data ini membuat peneliti tertarik untuk melakukan penelitian mengenai hubungan pengalaman psikologis, spiritual dan lingkungan dengan perilaku kekerasan pada siswa baru SMKN 3 Gorontalo. Penelitian tindak kekerasan pada siswa SMK juga jarang di temukan di lingkungan Kota Gorontalo dan ingin melihat potensi perilaku kekerasan pada siswa baru SMKN 3 Gorontalo.

\section{METODE}

Jenis penelitian ini menggunakan metode survey analitik dengan menggunakan pendekatan cross sectional. Penentuan sampel dilakukan dengan caraaccidental sampling, jumlah sampel sebanyak 253 orang. Analisis data menggunakan uji Chi-Square dengan tingkat kemaknaan $\alpha(0,005)$. SMKN 3 Gorontalo berada di Provinsi Gorontalo yang merupakan salah satu sekolah menengah kejuruan yang banyak diminati.

\section{HASIL}

Berdasarkan hasil penelitian didapatkan data karakteristik responden, analisis univariat dan bivariat pada tabel berikut ini :

Tabel 1. Karakteristik Demografi Responden

\begin{tabular}{|c|c|c|}
\hline Variabel & Jumlah (n) & Presentase $(\%)$ \\
\hline \multicolumn{3}{|l|}{ Usia } \\
\hline 15 tahun & 178 & 70,4 \\
\hline 16 tahun & 75 & 29,6 \\
\hline Total & 253 & 100 \\
\hline \multicolumn{3}{|l|}{ Jenis Kelamin } \\
\hline Laki-laki & 218 & 86,2 \\
\hline Perempuan & 35 & 13,8 \\
\hline Total & 253 & 100 \\
\hline
\end{tabular}


Tabel 2. Analisis Variabel Pengalaman Psikologis, Kondisi Spiritual, Lingkungan dan Perilaku Kekerasan

\begin{tabular}{|c|c|c|}
\hline Variabel & Jumlah & Presentase (\%) \\
\hline \multicolumn{3}{|l|}{ Pengalaman Psikologis } \\
\hline Baik & 220 & 87 \\
\hline Buruk & 33 & 13 \\
\hline Total & 253 & 100 \\
\hline \multicolumn{3}{|l|}{ Kondisi Spiritual } \\
\hline Baik & 212 & 83,8 \\
\hline Buruk & 41 & 16,2 \\
\hline Total & 253 & 100 \\
\hline \multicolumn{3}{|l|}{ Lingkungan } \\
\hline Baik & 136 & 53,8 \\
\hline Buruk & 117 & 46,2 \\
\hline Total & 253 & 100 \\
\hline \multicolumn{3}{|l|}{ Perilaku Kekerasan } \\
\hline Tidak Melakukan & 153 & 60,5 \\
\hline Melakukan & 100 & 39,5 \\
\hline Total & 253 & 100 \\
\hline
\end{tabular}

Tabel 3 Analisis Hubungan Pengalaman Psikologis, Spiritual dan Lingkungan dengan Perilaku Kekerasan

\begin{tabular}{|c|c|c|c|c|}
\hline \multirow[t]{2}{*}{ Variabel } & \multicolumn{2}{|c|}{ Perilaku Kekerasan } & \multirow{2}{*}{$\begin{array}{c}\text { Presentasi } \\
(\%)\end{array}$} & \multirow[t]{2}{*}{$P$ value } \\
\hline & Tidak PK & PK & & \\
\hline \multicolumn{5}{|l|}{ Pengalaman } \\
\hline \multicolumn{5}{|l|}{ Psikologis } \\
\hline Baik & $140(55.4)$ & $80(31,6)$ & 87 & 0,008 \\
\hline Buruk & $13(5,1)$ & $20(7,9)$ & 13 & \\
\hline Total & 153 & 100 & 100 & \\
\hline \multicolumn{5}{|c|}{ Kondisi Spiritual } \\
\hline Baik & $135(53,4)$ & $77(30,4)$ & 83,8 & \\
\hline Buruk & $18(7,1)$ & $23(9,1)$ & 16,2 & $\mathbf{0 , 0 1 8}$ \\
\hline Total & 153 & 100 & 100 & \\
\hline \multicolumn{5}{|l|}{ Lingkungan } \\
\hline Baik & $134(38,7)$ & $2(0,8)$ & 53,7 & $\mathbf{0 , 0 0 0}$ \\
\hline Buruk & $19(7,5)$ & $98(38,7)$ & 46,2 & \\
\hline Total & 100 & 153 & 100 & \\
\hline
\end{tabular}

\section{PEMBAHASAN}

Berdasarkan hasil penelitian yang telah dilakukan di SMKN 3 Gorontalo didapatkan bahwa Dari hasil uji chi-square diperoleh nilai $\rho=0,008(<0.05)$. Dengan demikian dapat dikatakan bahwa terdapat hubungan yang signifikan antara pengalaman psikologi dengan perilaku kekerasan pada siswa baru SMKN 3 Gorontalo.

Hasil penelitian mengenai data siswa dengan pengalaman psikologi baik dan tidak melakukan Perilaku Kekerasan adalah 140 responden dengan presentase 55,4\%.
Dan siswa dengan Pengalaman Psikologi buruk dan mengalami Perilaku Kekerasan sejumlah 20 responden dengan nilai presentase $7,9 \%$.

Saat diobservasi berdasarkan penelitian yang dilakukan, siswa dengan pengalaman baik dan tidak melakukan perilaku kekerasan dikarenakan anggota keluarga lain menyukainya, tidak memiliki pengalaman dengan orang yang mencoba menyentuh area privasinya, tidak disalahkan didepan banyak orang, orang tua perduli pada nutrisi, tidak dihukum dengan tidak adil di rumah, dan hidupnya berjalan 
dengan baik. Jumlah pernyataan ini dijawab oleh lebih dari 100 responden atau 71,4\%. Begitu pula dengan siswa psikologi buruk dan mengalami kekerasan.

Dari 20 responden yang memiliki pengalaman psikologi buruk dan melakukan perilaku kekerasan dijabarkan dalam kuisioner bahwa dirinya dididik dengan keras oleh orang tuanya, tidak diberikan perhatian, tidak bahagia, hidup berjalan kurang baik, istirahat kurang, dihukum dengan tidak adil di rumah dan orang lain pernah berbicara hal yang tidak baik dengan responden. Dari data ini menunjukkan bahwa kurangnya perhatian dari orang tua memberikan pengalaman buruk pada responden sehingga berpengaruh pada tingkah lakunya.

Hasil penelitian ini sejalan dengan teori yang telah ada dimana Pengalaman kekerasan yang dialami seseorang di masa lalu, baik secara langsung maupun tidak langsung merupakan salah satu faktor penyebab seseorang melakukan perilaku kekerasan. Apabila seseorang dalam kondisi yang mengingatkan mereka pada pengalaman yang pernah mereka alami, maka mereka akan cenderung melakukan hal yang serupa (Sulistiyo, Fransiska,2013). Teori ini didukung pula dengan penelitian dari Nindya tahun 2012 mengenai Hubungan antara Kekerasan Emosional pada Anak terhadap Kecenderungan Kenakalan Remaja yang hasilnya menunjukkan bahwa diketahui nilai koefisien Korelasi dalam penelitian tersebut adalah 0,288 dengan taraf signifikansi 0.000. Taraf signifikansi tersebut kurang dari nilai alpha $(0,05)$ yang menyebabkan hubungan antara kekerasan emosional dan kecenderungan kenakalan remaja signifikan.

Hasil penelitian yang di lakukan di
SMKN 3 Gorontalo untuk kategori pengalaman psikologi buruk tetapi tidak melakukan Perilaku Kekerasan berjumlah 13 responden $(5,1 \%)$. Dalam penelitian, diidentifikasi bahwasiswayang memiliki pengalaman psikologi buruk namun tidak melakukan perilaku kekerasan karena berdasarkan kuisioner siswa tidak diperbolehkan untuk merusak barang, menghina, mengintimidasi, menyuruh, memalak, mengadu domba, mengucilkan, mengancam, maupun melakukan terror. Jawaban-jawaban ini menunjukkan bahwa pengalamannya selama masa sekolahnya yang terdahulu melarang perilaku-perilaku seperti diatas dan membuat siswa menjadi lebih terkontrol dalam bertindak sehari-hari.

Hal ini didukung dengan teori yang menyatakan kontrol diri adalah kemampuan membimbing tingkah laku sendiri, kemampuan untuk menekan impuls-impuls atau tingkah laku impulsif. Kontrol diri merupakan kemampuan individu untuk menahan keinginan atau dorongan sesaat yang bertentangan dengan tingkah laku yang tidak sesuai dengan norma sosial (Sulistiyo, Fransiska, 2013) sedangkan penyesuaian diri dan pertumbuhan diri merupakan proses dalam hidup yang saling melengkapi, dimana kita menyesuaikan diri untuk survive dan karena pengalaman kita bertumbuh maka hidup kita akan lebih terarah (self-direction) dan penuh antusias (Dewi,2012)

Hasil penelitian untuk pengalaman Psikologi baik tapi melakukan Perilaku kekerasan sebanyak 80 responden $(31,6 \%)$. Berdasarkan hasil penelitian $62,5 \%$ dari 80 yang memiliki pengalaman psikologi baik tapi melakukan perilaku kekerasan menjawab pernah meninju teman, pernah ditendang teman, mendorong- dorong tanpa sebab, menyentuh bagian tubuh teman 
dengan tidak sopan, memanggil teman dengan ejekan, menyuruh teman melakukan hal yang tidak dikehendaki, menuduh, mengucilkan, menertawai di depan orang lain, danmenakut-nakuti. Padahal dari analisa jawaban di kuisioner pengalaman psikologi, responden mendapat keperdulian dari keluarga, tidak disalahkan didepan orang lain, harapan keluarga yang sesuai dengan kemampuan, hidup berjalan baik, istirahat yang cukup dan tidak pernah dihukum dengan tidak adil di rumah. Hasil ini menunjukkan bahwa faktor lain yang menyebabkan siswa melakukan kekerasan adalah faktor pergaulan dengan teman di tingkat sebelumnya.

Hal ini didukung dengan teori dari (Desmita,2009) yang menjabarkan pengaruh negative dari teman sebaya terhadap perkembangan anak-anak antara lain, anak yang diabaikan oleh teman sebayanya akan memunculkan perasaan kesepian atau permusuhan, budaya dari teman sebaya bisa jadi merupakan suatu bentuk kejahatan yang merusak nilai dan control orang tua, teman sebaya dapat mengenalkan anak kepada hal-hal yang menyimpang seperti merokok, alcohol, narkoba, dan sebagainya.

Perbedaan yang ditemukan ini didukung oleh penelitian sebelumnya oleh Putri tahun 2015 yang berjudul Faktor-Faktor Yang Berhubungan Dengan Perilaku Bullying Pada Remaja. Hasil penelitian sebelumnya didapatkan bahwa dukungan sosial teman sebaya yang negatif akan menyebabkan mayoritas remaja memiliki perilaku bullying tinggi yaitu 36 responden (75,0 $\%)$. Hasil statistik menunjukkan adanya hubungan antara dukungan sosial teman sebaya terhadap bullying ( $p$ value $=$ $0,000<\alpha)$. Pada masa remaja merupakan masa transisi dimana hubungan persahabatan dan dukungan teman sebaya sangat penting sehingga siswa menjadi mandiri dan tidak ketergantungan pada orang tua. Hubungantemansebaya yang tidak sehat akan sangat berdampak sehingga resiko terjadinya perilaku kekerasan semakin besar.

Berdasarkan pembahasan, teori yang mendukung dan penelitian yang berhubungan, peneliti berkesimpulan bahwa terdapat hubungan yang signifikan antara pengalaman psikologi dengan perilaku kekerasan pada siswa baru SMKN 3 Gorontalo. Artinya semakin baik pengalaman psikologi yang dimiliki siswa maka semakin kecil potensi siswa untuk melakukan kekerasan begitu pula sebaliknya.

Selain faktor pengalaman psikologi terdapat juga faktor spiritual. Berdasarkan hasil penelitian yang telah dilakukan di SMKN 3 Gorontalo didapatkan bahwa Dari hasil uji chi-square diperoleh nilai $\rho=$ $0,018(<0.05)$. Dengan demikian dapat dikatakan bahwa terdapat hubungan yang signifikan antara spiritual dengan perilaku kekerasan pada siswa baru SMKN 3 Gorontalo.

Hasil penelitian mengenai data siswa dengan spiritual baik dan tidak melakukan Perilaku Kekerasan adalah 135 responden dengan presentase $53,4 \%$. Dan siswa dengan kategori spiritual kurang dan mengalami Perilaku Kekerasan sejumlah 41 responden dengan nilai presentase $9,1 \%$. Pada penelitian siswa yang memiliki spiritual baik dan tidak melakukan perilaku kekerasan memiliki criteria yang sama pada pernyataan tidak merusak barang, tidak menghina, tidak memalak, tidak mengadu domba teman, tidak memberikan ancaman adengan ejekan maupun kata-kata kasar dimana jawaban ini menggambarkan bahwa 
siswa tidak melakukan tindakan-tindakan diatas dan hasil ini didapatkan pada $89 \%$ dari 135 siswa dengan spiritual baik dan tidak melakukan perilaku kekerasan.

Sedangkan yang memiliki spiritual yang buruk dan melakukan perilaku kekerasan dikarenakan siswa memiliki poin kurang pada pernyataan ketika waktu sholat tiba, tidak segera melaksanakan, kurang baik dalam menyampaikan amanat, melakukan perbuatan yang dilarang oleh agama saat sedang berduaan dengan lawan jenis, masih merasa kecewa pada orang yang telah menyakiti, dan menghalalkan segala cara untuk mendapatkan apa yang diinginkan. Selain itu dari 23 responden kondisi spiritual rendah dan melakukan perilaku kekerasan yang menjawab pernah ditendang tanpa sebab oleh temannya sebanyak 20 orang, mendorong-dorong tanpa sebab dijawab pernah oleh 23 responden, menertawakan teman saat melakukan kesalahan sebanyak 22 orang, dan menakut-nakuti teman sebanyak 20 orang. Kondisi spiritual yang rendah ini memiliki dampak yang besar terhadap responden dalam melakukan tindakan seperti penjabaran dari poin-poin kuisioner diatas.

Hasil penelitian ini sejalan dengan teori yang telah ada dimana Andisty \& Ritandyo (2008) menyatakan tingkat religiusitas yang tinggi pada remaja ditunjukkan dalam perilaku yang sesuai dengan ajaran agama yang dianutnya karena memandang agama sebagai tujuan hidupnya sehingga remaja berusaha menginternalisasikan ajaran agamanya dalam perilaku sehari-hari. Hal tersebut dapat dipahami karena agama mendorong pemeluknya untuk berperilaku baik dan bertanggung jawab atas perbuatannya. Selain itu, agama selalu mendorong umatnya untuk berbuat kebajikan.

Teori ini didukung pula dengan penelitian oleh Astiningrum, (2013) tentang hubungan antara kecerdasan spiritual dengan kenakalan remaja di SMAMuhammadiyah 2 Genteng yang hasil analisa data menggunakan korelasi product moment dengan hasil korelasinya $-0,681$, dimana $\mathrm{p}>0,05$, maka terdapat hubungan negatif antara kecerdasan spiritual dengan kenakalan remaja yakni semakin tinggi kecerdasan spiritual yang dimiliki, maka kenakalan semakin rendah begitu pulasebaliknya.

Hasil penelitian yang di lakukan di SMKN 3 Gorontalo pada siswa baru untuk kategori spiritual kurang tetapi tidak melakukan Perilaku Kekerasan berjumlah 18 responden (7,1\%). Berdasarkan penelitian untuk siswa yang memiliki spiritual kurang tetapi tidak melakukan perilaku kekerasan, menunjukkan bahwa hampir semua pernyataan berjumlah hanya $27 \%$ yang melakukan perilaku kekerasan. Siswa tidak melakukan perilaku kekerasan seperti tidak memukul, merusak barang, memanggil teman dengan julukan yang tidak baik, tidak menghina, mengintimidasi, menyuruh teman melakukan yang tidak dikehendaki, memalak, mengadu domba, mengacuhkan, menuduh mengucilkan dan pernyataan-pernyataan lainnya dikuisioner kecuali pada poin pernah ditendang dengan sengaja oleh teman, mendorong-dorong adalah hal biasa, menyentuk bagian tubuh teman dengan tidak sopan, menertawai teman dan menakut-nakuti teman. Bahkan pada poin menghina teman dan meneror tidak ada satupun yang melakukan tindakan tersebut. Dan dari kuisioner spiritual responden sebagian besar menjawab pertanyaan dengan baik pada poin memasrahkan hasil kepada Allah, 
membantu orang lain dengan ikhlas, menyampaikan amanat dengan baik, tidak mengambil hak orang lain, dan tidak memarahi pengemis yang datang dirumah.

Dari hasil yang didapatkan ini menunjukkan bahwa siswa yang tidak melakukan perilaku kekerasan karena kecerdasan emosi yang dimilikinya. Dimana responden sadar bahwa sesuatu yang dilakukan tanpa menimbulkan kerugian bagi orang lain akan dirasakan lagi olehnya suatu saat. Oleh sebab itu, responden-responden berusaha untuk tidak melakukan perilaku kekerasan selama masasekolahnya.

Hal ini sejalan dengan teori Goleman (2009) menyatakan bahwa secara umum ciri-ciri seseorang memiliki kecerdasan emosi adalah mampu memotivasi diri sendiri, mengendalikan dorongan hati dan mengatur suasana hati dan menjaga agar beban stres tidak melumpuhkan kemampuan berfikir.

Teori ini ditunjang dengan penelitian yang relevan oleh Mutia tahun 2017 tentang hubungan kecerdasan emosi dengan kenakalan remaja di SMP PGRI 7 Samarinda dengan hasil dari uji hipotesis menunjukkan adanya pengaruh signifikan antara variabel kecerdasan emosi dengan kenakalan remaja (Y) karena nilai $\mathrm{p}=0,000$ $(<0,05)$ dengan nilai koefisien korelasi $\mathrm{r}=$ 0,604. Artinya jika kecerdasan emosi meningkat maka tingkat kenakalan remaja menurun dan jika kecerdasan emosi menurun maka tingkat kenakalan remaja meningkat.

Hasil penelitian untuk pengalaman Spiritual baik tapi melakukan Perilaku kekerasan sebanyak 77 responden $(30,4 \%)$. Berdasarkan hasil observasi melalui kuisioner siswa dengan spiritual baik tetapi melakukan perilaku kekerasan siswa 65 responden (84\%) menjawab bahwa mereka pernah dorong mendorong teman tanpa sebab, menertawai teman dan menakutnakuti. Begitu pula pada kuisioner kondisi spiritual yang menyatakan bahwa 70 responden $(90 \%)$ memasrahkan hasilkepada Allah, membantu dengan ikhlas, menyampaikan amanat dengan baik dan menerima pengemis yang datang kerumah.

Dari fenomena yang ada menunjukkan bahwa tingkat spiritual yang tinggi tidak menutup kemungkinan untuk melakukan kenakalan remaja. Menurut Yuanita (2011) rasa ingin tahu di dorong dengan kebutuhan manusia itu sendiri. Adanya rasa ingin tahu yang besar maka manusia akan mulai berpikir dan memulai mencari jawaban yang sebanyak-banyaknya. Karena pada usia remaja merupakan usia yang labil terutama pada siswa yang masuk di lingkungan yang baru, dimana mereka sangat mudah sekali dipengaruhi oleh lingkungan sekitar. Para remaja mempunyai rasa ingin tahu yang tinggi, dan bila mereka sudah mengetahui maka mereka inginmelakukan.

Hal ini ditunjang dengan penelitian sebelumnya oleh Nisya tahun 2012 mengenai religiusitas, kecerdasan emosional dan kenakalan remaja yang menyatakan bahwa hasil uji korelasi antara religiusitas dengan kenakalan remaja diperoleh nilai rx1y sebesar 0.106 dengan $\mathrm{p}$ $=0.331 ; \mathrm{p}>0.05$, maka tidak signifikan. sehingga disimpulkan bahwa tidak ada korelasi antara religiusitas dengan kenakalan remaja.

Berdasarkan pembahasan, teori yang mendukung dan penelitian yang berhubungan, peneliti berkesimpulan bahwa terdapat hubungan yang signifikan antara spiritual dengan perilaku kekerasan pada siswa baru di SMKN 3 Gorontalo. 
Artinya semakin baik spiritual yang dimiliki siswa maka semakin kecil kemungkinan untuk melakukan tindak kekerasan. Selain faktor pengalaman psikologi dan spiritual, terdapat juga faktor lingkungan. Pada penelitian ini didapatkan hasil penelitian bahwa terdapat hubungan antara karakteristik lingkungan dengan perilaku kekerasan pada siswa baru SMK Negeri 3 Gorontalo.

Responden dengan karakteristik lingkungan baik dan tidak mengalami perilaku kekerasan berjumlah 134 responden (53.0\%). Peneliti berasumsi bahwa dalam lingkungannya mereka sudah diajarkan norma dan etika yang baik. Seperti halnya yang disampaikan oleh Sulistyowati (2014), keluarga merupakan kunci penting anak dalam berperilaku karena di dalam keluarga inilah norma dan nilai akan ditanamkan kepada anak. Di dalam keluarga, anak diajarkan kemampuan untuk menahan perilaku negatif yang akan diterimanya dalam pergaulan. Perlakuan yang diterima anak dalam keluarga baik dari orang tua maupun saudara turut membentuk perilaku anak di sekolah maupun masyarakat. Oleh karena itu, sudah merupakan keharusan untuk membentuk iklim keluarga yang kondusif bagi pembentukan perilaku anak.

Hal ini sejalan dengan penelitian yang dilakukan oleh Sulistyowati (2014) dimana dari hasil penelitian terdapat hubungan yang positif antar lingkungan sekolah dengan perilaku kekerasan, dimana responden yang memiliki nilai lingkungan yang tinggi, maka akan cenderung berperilaku baik. Selain itu, hasil penelitian juga menunjukan bahwa semakin tidak baik karakteristik lingkungan seorang responden, maka responden tersebut cenderungmengalami perilaku kekerasan.
Dalam penelitian ini sendiri terdapat 98 responden (38.7\%) dengan karakteristik lingkungan yang tidak baik dan mengalami perilaku kekerasan. Hasil penelitian ini sejalan dengan teori Kartono dan dan Sulistyowati (2014) dimana faktor eksternal seperti lingkungan keluarga dan teman sebaya mempengaruhi seseorang melakukan perilaku kekerasan. Lingkungan keluarga merupakan bentuk kecil dari masyarakat dan kehidupannya, dimana pandangan anak dalam masyarakat akan dipengaruhi oleh pola dalam keluarga tersebut. Keluarga merupakan kunci penting anak dalam berperilaku karena di dalam keluarga inilah norma dan nilai akan ditanamkan kepada anak. Di dalam keluarga, anak diajarkan kemampuan untuk menahan perilaku negatif yang akan diterimanya dalam pergaulan. Perlakuan yang diterima anak dalam keluarga baik dari orang tua maupun saudara turut membentuk perilaku anak di sekolah maupun masyarakat. Kualitas rumah tangga atau kehidupan keluarga memainkan peranan paling besar dalam membentuk kepribadian remaja. Misalnya rumah tangga yang disebabkan karena kematian ayah atau ibu, perceraian orangtua, keluarga yang diliputi konflik besar, semua itu merupakan sumber yang memunculkan perilaku agresif pada remaja.

Selain keluarga, pengaruh kelompok teman sebaya memberikan pengaruh terhadap tumbuhnya perilaku kekerasan di sekolah. Teman di lingkungan sekolah idealnya berperan sebagai "partner" siswa dalam proses pencapaian program-program pendid ikan. Namun kelompok teman sebaya yang memiliki masalah di sekolah akan memberikan dampak yang negatif bagi sekolah seperti kekerasan, perilaku membolos, dan rendahnya sikap 
menghormati kepada sesama teman dan guru.

Perilaku kekerasan yang terjadi di sekolah juga sebagian disebabkan karena adanya dorongan dari teman-temannya. lingkungan tidak selamanya baik dan menguntungkan bagi perkembangan remaja. Lingkungan adakalanya dihuni oleh orang dewasa serta anak-anak muda kriminal dan anti-sosial yang bias merangsang timbulnya reaksi emosional buruk pada anak-anak puber dan adolesens yang masih labil jiwanya. Anak remaja cenderung melakukan prosespeniruan pada apa yang dilihatnya. Lingkungan merupakan ranah terdekat dalam keseharian para remaja baik keluarga, teman sebaya, maupun masyarakat. Oleh karena itu, baik buruknya kondisi lingkungan sangat mempengaruhi seorang remaja dimasa depan (Kartono, 2014).

Usman (2013) dalam penelitiannya peneliti menemukan beberapa kasus kekerasan. Sebagian besar mengemukakan bahwa mereka pernah melihat dan menjadi pelaku kekerasan. Adapun bentuk-bentuk kekerasan yang pernah terjadi antara lain seperti menyuruh push up, membentak, memelototi, memalak, mengejek dan yang paling ekstrim adalah pemukulan. Berdasarkan hasil wawancara disimpulkan bahwa perilaku kekerasan yang terjadi pada beberapa sekolah merupakan tindakan yang dilakukan oleh kakak kelas kepada adik kelas. Hal ini menunjukkan bahwa senioritas masih menjadi sebuah fenomena yang terus terjadi di sekolah. Adanya ketimpangan atau ketidakseimbangan kekuatan baik fisik maupun mental menjadi penyebab terjadi perilaku kekerasan di sekolah. Di samping itu pula dari beberapa orang siswa melaporkan bahwa siswa yang melakukan perilaku bullying itu disebabkan adanya faktor balas dendam. Ketika para siswa masih berstatus siswa baru di sekolah tersebut, para siswa mendapatkan perlakuan kekerasan dari kakak kelas sehingga ketika para siswa menjadi senior siswa ini memperlakukan hal yang sama kepada siswa-siswa junior.

\section{SIMPULAN}

Hasil uji chi-square menunjukkan terdapat hubungan antara pengalaman psikologi, spiritual dan lingkungan dengan perilaku kekerasan pada siswa baru SMK Negeri 3 Gorontalo dengan hasil uji chisquare diperoleh nilai $\rho=<0.05$.

\section{DAFTAR PUSTAKA}

Andisti, M.A., Dan Ritandiyono. 2008.Religiositas Dan Perilaku Seks Bebas Pada. Dewasa Awal. Jurnal Psikologi. Jakarta:Universitas Gunadarma

Astiningrum, Febriana. 2013. HubunganAntara Kecerdasan Spiritual Dengan Kenakalan Remaja di SMA Muhammadiyah 2 Genteng. Skripsi. Malang:Fakultas Psikologi. Universitas Islam Negeri Maulana Malik Ibrahim

Carpenito, L. J. And Moyet. 2016. Buku Saku Diagnosis Keperawatan Edisi 13. Jakarta: EGC

Desmita.2009. Psikologi Perkembangan Peserta Didik. Bandung : Remaja. Rosdakarya

Dewi, Kartika Sari. 2012. Buku Ajar KesehatanMental.Semarang:UPTUN DIP Press

Goleman, Daniel. 2009. Kecerdasan Emosional : Mengapa EI lebih penting daripada IQ. Jakarta : PT. Gramedia Pustaka Utama.

Hamid, Achiryani.2008.Aspek Spiritual Dalam Keperawatan. Jakarta: Widya Medika

Imaroh, Zidti. 2017. Hubungan Kecerdasan Spiritual Terhadap Risiko Perilaku 
Bullying Siswa Di SMK Yayasan

Miftahul Jannah (YMJ) Ciputat.

Skripsi. Jakarta: Universitas Islam

Negeri SyarifHidayatullah

King, Pamela Ebstyne, and Casey E Clardy. 2014. "Adolescent Spiritual Exemplars :Exploring Spirituality in theLivesof Diverse

Youth."Journal ofAdolescent

Research 29(186-212).

Marhaeni, Dwi Pangastuti. 2012. Intensitas

Peran Komunikasi Interpersonal Dalam Keluarga Untuk Mencegah Kenakalan Remaja. Jurnal. Jurusan Ilmu Komunikasi FISIP Universitas Jenderal Soedirman

Mutia,Adelia. 2017. Hubungan

Kecerdasan Emosi Dengan

Kenakalan Remaja di SMP PGRI 7 Samarinda.Jurnal.Samarinda:Fakult as PsikologiUniversitas17Agustus 1945 Samarinda

Nindya P. N, Margaretha R. 2012.Hubungan antara Kekerasan Emosional padaAnak terhadap Kecenderungan Kenakalan Remaja. Jurnal.Surabaya:Fakultas Psikologi Universitas Airlangga Surabaya

Nisya, Lidya Sayidatun. 2012. Religiusitas, Kecerdasan Emosional Dan

Kenakalan Remaja.Jurnal. Kediri: Universitas PGRI Nusantara.

Palupi,Atika Oktaviani. 2013. Pengaruh Religiusitas Terhadap Kenakalan. Remaja Pada Siswa Kelas Viii Smp Negeri O2Slawi.Skripsi, Jurusan Psikologi Fakultas Ilmu Pendidikan,Universitas Negeri Semarang

Putri, Hertika Nanda. 2015. Faktor-Faktor Yang Berhubungan DenganPerilaku Bullying Pada Remaja. Jurnal. Riau: PSIK UniversitasRiau

Riskinayasari, Gilda. 2015. Kenakalan Remaja Ditinjau Dari Konsep Diri Dan Jenis Kelamin. Skripsi. Surakarta: Fakultas Psikologi Universitas Muhammadiyah Surakarta.

Sulistiyo, Fransiska Septiana. 2014. Pengaruh Lingkungan Sekolah
Dan Pengetahuan Terhadap

Perilaku Kekerasan Di kalangan Pelajar. Tesis. Surakarta: Program Pasca Sarjana Universitas Sebelas Maret

Suryabatra, Sumardi. 2013. Psikologi Kepribadian. Jakarta: PT Raja GrafindoPersada

Trisnawati, Junia. 2014. Faktor-

Faktor Yang Mempengaruhi Perilaku Agresif Remaja Di Smk Negeri 2 Pekanbaru. Jurnal. Program Studi Ilmu Keperawatan. Universitas Riau. 